\title{
Ice-Candy-Man and In the Country of Men: The politics of cruelty and the witnessing child
}

\author{
Annie Gagiano \\ Department of English, Stellenbosch University, Private Bag X1, 7602 Matieland, South Africa \\ Email: ahg@sun.ac.za
}

\begin{abstract}
Using two novels employing child narrators as observers of atrocities by which they are not only profoundly affected, but in which they become implicated (respectively by a Pakistani and a Libyan author), the article sets out to try and discover how the technique of mediation by a child witness and commentator affects the reader's perception of the Partition of Pakistan from India and the early rule of Gen. Quaddafi [or Gaddafi] in Libya, North Africa. The children are pre-pubescent, but intensely aware of sexual politics and emotional cross-currents in their familial, domestic, neighbourly and social contexts as the harsh and terrible political realities of their time and setting either filter into or impact violently upon their own lives.

The offered reading is contextualized by considerations of postcolonial texts (as both Sidhwa's IceCandy-Man [also known by the American title of Cracking India] and Matar's In the Country of Men are, broadly speaking) as writings that can serve inter-cultural and trans-modern 'translation' purposes -- not only by their publication in English (neither author's first language), but by using each of their child narrators to make cultural 'differences' (inter-)accessible to their readers. The emphasis in both texts on non-Western cultures nevertheless does not (in either case) allow stereotypical concepts concerning members of those cultures (e.g. as being inexplicably inclined to cruelty or violence) to prevail. The profoundly affective power of the descriptions of atrocities in both books (intensified by being observed in relatively unideological and unfiltered ways) become ethical challenges to the reader.

The comparative reading techniques employed in the essay are used to sharpen the focus on how each of the children is ineluctably affected by what she or he witnesses and to indicate how both of them are 'betrayed into betrayal'.
\end{abstract}

Keywords: Child narrator; trans-cultural; comparative reading strategy; affective power; betrayal

\section{Introduction}

In this essay I will bring together a novel set in North Africa with a novel from Asia. The first novel is Bapsi Sidhwa's Ice-Candy-Man (1989 [1988]) ${ }^{1}$ which is set during the 1947 Partition of Pakistan from India that coincided with independence for both territories from British colonial rule. The events of the time set Muslims, Hindus and Sikhs against one another in deadly territorial rivalries that manifested also in especially high levels of violence against and violations of women's bodies and persons. The events are observed by an eight-year-old Parsee girl, Lenny, whose closest companion is her Hindu Ayah, Shanta. The nadir of the 
narrative is the abduction to gang rape and forced prostitution of Ayah (as Lenny always names her). A counterpart on a more minor narrative scale is the devastation of a Muslim village in the Punjab by Akali Sikhs during which mass rape and murders are observed by a little boy, the great-grandson of Lenny's family's cook. The Ice-candy-man of the title is the chief orchestrator of Shanta's abduction. In committing such an atrocity he 'avenges' his longthwarted desire for her and also enacts a ritual vengeance for the sexual mutilations, murders and violations of his female Muslim relatives by Hindus and Sikhs. Towards the end of the text Shanta is rescued from her forced marriage to him; she is broken-spirited, but returns to her people. This novel has been widely read and a number of good critical articles - e.g. by Mann (1994), Didur (1998), Singh (2004) and Mitra (2008) - have addressed it; with Hai (2000) mounting a more questioning and questionable reading. Sidhwa has also given interviews about this text, for example with Bruschi (2008).

The second novel we will be looking at, is Hisham Matar's In the Country of Men (2006). This novel depicts a nine-year-old boy - Suleiman - in Tripoli, Libya, during the early years of the rule of Qaddafi (or Gaddafi), when this "revolutionary" government intensified its repression of dissent in increasingly sinister and violent (but widely popular) ways. The boy is a lonely only child who spends most of his time looking after his young mother, who is addicted to alcohol which she uses as comfort source when her husband is away - in a country where drinking is considered a sin, both shameful and illegal. The mother bewails her forced marriage at fourteen and is scornful of and troubled by what she sees as her husband's foolish risk-taking in organising resistance against the powerful military regime. She is proved right when the boy's father is later (like his friend, their neighbour, earlier) arrested and tortured. The neighbour is publicly executed in a televised ritual of cruel power and mob mania. The mother pleads with another neighbour, a high-ranking officer in the secret police, to have her husband released. Soon after the father's return, the boy is sent to Egypt to save him from military conscription of fourteen-year-old boys. He never sees his father or his country again and is branded a traitor for evading conscription. His mother reverts to alcoholism when his father is later arrested again; the father dies not long after his second release. Scholarly articles on Matar's novel are still rare; Scanlan's (2010) was the only one found, in addition to my own brief (2007) piece on it which appeared in my column "The African Library".

\subsection{The trans-modern, translating role of the postcolonial text}

The argument for the inter-cultural, trans-modern and "translating" function of the postcolonial text that I use in this article to frame my comparative discussion of two novels is, in many ways, already encapsulated in the three concluding stanzas of Wallace Stevens's poem "The Novel". In these lines, given below, the poetic speaker marvels at how the reader becomes vicariously involved during the concentrated reading of a novel - even if the protagonist is a member of a culture distant and different from one's own:

It is odd, too, how that Argentine is oneself, Feeling the fear that creeps beneath the wool, Lies on the breast and pierces into the heart,

Straight from the Arcadian imagination, Its being beating heavily in the veins, Its knowledge cold within one as one's own; 
And one trembles to be so understood and, at last, To understand, as if to know became

The fatality of seeing things too well.

(Stevens 1990:458-459)

Stevens's example of a protagonist with whom the (non-Argentinian) reader identifies - "that Argentine" - is the first pointer to the border-crossing feat achieved by vivid fiction and the way self-assured postcolonial authors break through the "othering" barriers set up by racial and other condescending, hierarchising attitudes ${ }^{2}$. The poem appeared in a 1950 Stevens collection, when the "fear" ascribed to "that Argentine" would have alluded to political repression and violence of a kind similar to that which is observed and illustrated in both of the novels with which this article is primarily concerned.

Although in this essay the expression "postcolonial novel" is useful, it is employed in full awareness of a growing realisation among literati of the awkwardness and increasing inaccuracy of the term. Sidhwa's novel indeed depicts the historic moment of the Partition between India and Pakistan at the cessation of British colonial rule over the entire area, but Matar's Libyan setting invokes a society from which Italian and earlier colonial powers have long departed - and neither his nor Sidhwa's text is centrally concerned with the colonial power or influence. They are, however, novels that do preoccupy themselves with recently established state formations and fervently nationalist societies - conditions that tellingly connect, as a loose genre, novels from such regions - distinguishing them in these respects from those written in the previously colonising or long-since independent regions or states which we term "the West". As examples of postcolonial texts, the novels discussed here thus belong to what might be distinguished as the "second wave" of postcolonial writing, that is, works that concern themselves with local (personal, familial, social, and political) conditions rather than lingering colonial influences. Compare Bart Moore-Gilbert's definition of postcolonial criticism as:

a set of reading practices ... preoccupied principally with analysis of cultural forms which mediate, challenge or reflect upon the relations of domination and subordination - economic, cultural and political.

(Moore-Gilbert 1997:12)

The one glaring omission from Moore-Gilbert's description (above) is an issue central to both novels and to the comparative reading perspectives invoked here, viz. the two novelists' concern with gendered power relations in both societies. While both novels depict horrific demonstrations of savagery violently inflicted on male bodies, both texts seem to suggest that how women are treated and their social status serve to measure the moral-political texture of a state.

The chosen novels depict the employment of extreme violence and the ruthless invasion of family homes in the course of state transformation - an intensifying post-revolutionary dictatorship in Libya, and ethnic cleansing and community displacement in the formation of Pakistan upon its severance from India. Neither novelist represents their compatriots including those who execute acts of dreadful cruelty - as sub-human, unrecognisable "others", even while unflinchingly evoking (through the eyes of the two child protagonists) their deeds. Implicit in both novels is a sense of grief and loss and a plea for a re-humanising transformation of the spaces and places where local blood was spilt in regimes of terror, 
respectively African and Asian. I want to argue furthermore that, by writing their texts in English, Matar and Sidhwa address both their present and remaining compatriots in an implicitly exhortatory manner and appeal to a global readership to make the effort to achieve a non-condescending comprehension of the social and moral complexities of distant and different areas and those who inhabit them. It matters too that, at a time when recent events have if anything intensified the "Western", English-speaking world's prejudices against Muslim subjects and cultures, both novels are set in areas where Islam is the predominant religious adherence.

\subsection{Perspectives from Bakhtin, Lara and others}

Both novels can be said to portray and assess political conditions and also to adopt implicit (though complex) moral advocacy. This does not in any way detract from their literary worth. As Mikhail Bakhtin stated in a now classic essay:

The prose art presumes a deliberate feeling for the historical and social concreteness of living discourse, as well as its relativity, a feeling for its participation in historical becoming and in social struggle; it deals with discourse that is still warm from that struggle and hostility, as yet unresolved and still fraught with hostile intentions and accents; prose art finds discourse in this state and subjects it to the dynamic unity of its own style.

(Bakhtin 1990:331)

Chinua Achebe, in response to certain criticisms of his postcolonial novels, gave impatient expression to his irritation with denigration of "engaged" literature by stating: "Art for art's sake is just another piece of deodorised dogshit. [...] art is and has always been in the service of man" (Achebe 1975:19). Bakhtin phrases a comparable point somewhat more circumspectly, writing of the distinctive and innovative quality of the novel as art form as being constituted by its "special relationship with extraliterary genres, with the genres of everyday life and with ideological genres." For the novel, he avers, "is constructed in a zone of contact with the incomplete events of a particular present" (Bakhtin 1990:33). Bakhtin also validates interpretative engagement with the political and polemical dimensions of novels, insisting that stylistic analysis "necessitates first and foremost profound artistic and ideological penetration into the novel". He adds to this (in a footnote to the aforegoing comment): "Such insight also involves a value judgement on the novel, one not only artistic in the narrow sense, but also ideological - for there is no artistic understanding without evaluation" (Bakhtin 1990:416, emphasis added). I emphasise Bakhtin's term "ideological" above, because his pronouncements help to delineate the chosen authors' use in both novels of a prepubescent narrator-observer and protagonist to draw the reader's attention to the political (including, in this term, the gender) dimensions of events unfolding in Pakistan at Partition and in Libya under Gaddafi.

The "developmental" and "educational" work legitimately and usefully undertaken by the novel seems to be a point in constant need of reiteration (or rediscovery) by authors and critics. In an essay collection published in 1984, George Lamming writes of the West Indian novel - in a comment that is also more generally applicable, particularly to postcolonial texts - referring to "the discovery of the novel [...] as a way of investigating and projecting the inner experiences of the [...] community" (Lamming 1984:37). I wish to link this and other aforegoing points to the following analysis by a more recent theorist (Lara 1998) of the novel's involvement in the struggle for recognition of oppressed or denigrated groups. 
[...] for a group to gain esteem and recognition [...] requires entering into the convoluted, interlarded language of public life with illocutionary force, with such creative rhetorical power and non-institutionalized resources that one's own and other's identities seem to require a reconstructed narrative of the social, one that is coded in much more democratic, egalitarian and humanitarian terms.

(Lara 1998:136)

Maria Pia Lara, a Mexican philosopher and the author of the above citation, wrote an important study of the novel that focuses primarily on feminist narratives, but is usefully applicable to the public function of postcolonial novelistic narratives. In the present article, Lara's ideas about the work done in and by novels is put into connection and in juxtaposition with some of Bakhtin's suggestions, as well as with those occurring in the poem by Wallace Stevens, to draw attention to the border-crossing or cultural translation achieved for their societies by Sidhwa and Matar. Like Stevens, Lara writes of the transforming enlightenment achieved in the reader by powerfully evocative fiction when "[t]ransformations entail a 'fusion of horizons', a new and novel way of understanding oneself". However, she adds that "no solidarity is possible if the discourse does not form a bridge to the other's understanding of what are considered to be worthy features and needs of human beings" (Lara 1998:157). Such bridging functions as translation among individuals and cultures.

\subsection{Comparative reading}

In the previous section we presented some contextualising notions concerning works depicting such profoundly troubled and troubling sociopolitical contexts. Keeping these notions in mind, the decision to use a comparative reading strategy will now be addressed. The preceding paragraphs have mentioned several of the aspects that the two chosen texts have in common with each other and with other postcolonial novels. While both Sidhwa's 1988 novel and Matar's more recent (2006) text are absorbing and skillful works of narrative fiction, casting light on politically fraught societies and situations not often rendered in such complex detail, the most obviously comparable aspect of the two texts is the use in each of them of a young child as witness-commentator. As a novelistic device, the idea is not new. In the British/American tradition some of the best known examples are [the first part of] Dickens's Great Expectations (1860/1), Twain's Huckleberry Finn (1884), James's What Maisie Knew (1897), Lee's To Kill a Mockingbird (1960) and McEwan's Atonement (2001). Among well over fifty relatively recent examples of child-narrated texts from Africa one might mention Laye's The African Child (1953) [Laye's being a translation from French], Jumbam's The White Man of God (1980) and Okri's The Famished Road (1991). From the Indian sub-continent, Narayan's Swami and Friends (1935) and Rushdie's Midnight's Children (1980) are notable examples, while some of the most arresting sections of Roy's The God of Small Things (1997) also employ twin child protagonists' perspectives. The effectiveness of skilfully portrayed child protagonists and child-narrated novels is indeed confirmed by the fact that so many of these texts are considered classics of world literature. While Sidhwa's and Matar's novels are in no way unmediated autobiographies, they are based on each author's actual childhood experiences as witnesses to harrowing events and circumstances like those portrayed in their texts, the novelists having lived as children respectively in Lahore and Tripoli $^{3}$. Their texts do not however contain discernible intertextual references to other childnarrated works. The mainly comparative reading perspective employed in this paper thus restricts itself to these two primary texts, although some of the points made about the function of the child protagonists would clearly apply to other such child characters in other texts. 
Comparative reading practice is both difficult and rewarding. It is taxing in that it requires both adroitness and care to avoid further distortions over and above the inevitably reductive and selective effects of any interpretation of a single text; when what is comparable about two texts is allowed to outweigh what is unique to each. It is, however, rewarding in cases where each of the two works brought together illuminates aspects of the other, or when the comparison fruitfully accentuates details that might previously have gone unnoticed. At its best, it can help the reader to think more deeply about the issues raised in both texts. Reading texts from different regions comparatively facilitates bridging among cultures and border crossings between readers' localised knowledge, on the one hand, and insights emanating from very different locales and made accessible fictionally, on the other. Comparative reading works against possible ghettoisation effects of postcolonial reading practices that may still (inadvertently) exoticise or "other" texts from areas such as Africa, India and South America. Ideally, comparative reading practice can bring marginalised texts to attention and convey a degree of understanding of the "distant" or "different" societies from which they emanate - at the same time lifting such texts out of immersion in their local cultures or societies, whether Western or from the "global South".

Gayatri Spivak (2003:100) was not wrong to enjoin comparatists "persistently and repeatedly [to] undo the definitive tendency of the dominant to appropriate the emergent" (or, say, the postcolonial) culture, but Lara and Bakhtin both make points that are more apposite to the kind of comparative literary practice adopted in the present essay. For instance, Lara writes:

Cultures may survive or not, depending on the capacity for transformation which springs from their critical vision and the permanent revision of their legacy, $[\ldots]$ However $[\ldots]$ an identity of one's own $[\ldots]$ must prove itself [...] by undertaking a dialogue of recognition in its interaction with other cultures.

(Lara 2003:159)

Bakhtin for his part celebrates a type of dislodgement that occurs when a local culture is no longer attached only to its own locality and reality: "This verbal-ideological decentering will occur when a national culture loses its sealed-off and self-sufficient character, when it becomes conscious of itself as only one among other cultures and languages" (1990:370, original italicised). It is, thus, not only "the metropolitan comparatist" - as Spivak would have it - but all comparatists who "must imagine planetarily" (Spivak 2003:98).

\section{Child protagonists' witnessing}

In his essay entitled "Transcultural identity in African narratives of childhood", Richard Priebe (2006:50-51) writes that "most recent writers of childhoods [...] [register] that instead of living in a multi-cultural world made up of easily identifiable cultures, we are living in a more fluid transcultural or even transnational world." While this may initially seem true of Sidhwa's protagonist Lenny's perception in Ice-Candy-Man, and of Matar's protagonist Suleiman's in In the Country of Men, both these child witnesses register rapidly intensifying, violently reductive and socially narrowing processes during the course of their narratives. In Ice-Candy-Man, the girl Lenny notices, as an ominous sign of the impending murderous, ethnically divisive bloodshed, how the social atmosphere in Lahore changes. "One day everybody is themselves -" she remarks, "and the next day they are Hindu, Muslim, Sikh, Christian" as "people shrink, dwindling into symbols" (Sidhwa 1989:93). Subsequent to the ethnic cleansing horrors, she observes how "Muslim families [...] now monopolise the 
[public] garden, depriving it of colour" (Sidhwa 1989:236). She also sees that now "there are fewer women. More men" (Sidhwa 1989:237) in public places. In Suleiman's home, as depicted in Matar's novel, the walls are covered in Italian wallpaper; their family friend is the son of an Egyptian judge practising in Libya as a lawyer and his son (albeit ill-advisedly) imports and sells tyres from Poland. Political dissent, though expressed anonymously or secretly, is still possible - until repression intensifies and people are denounced, imprisoned, tortured and publicly executed (or banished) for questioning, criticising or demonstrating against the regime. Witnessing the arrest of his best friend's gentle and scholarly father, the boy observes that "to see how [...] there's no space to argue, to say no, made my belly swim" (Matar 2006:33).

In both these novels, the child protagonist's observations function to validate points about the tragic loss or diminution of social diversity and political freedom that, if made by an adult observer, might have been less convincing, or suspected of ideological bias. Even though both these child witnesses to political threat and atrocity are often confused and at times mistaken about what they notice, their youth engenders trust in their probable veracity as witnesses. Young children are only beginning the socialisation process and are necessarily to an extent outsiders; minors without access to political power - hence their feelings and thoughts are unlikely to be (as yet) ideologised. In Matar's novel Suleiman's older friend tells him: "'Children are useless in a war'" (Matar 2006:27), while an adult in Sidhwa's text pronounces: "'Children are the Devil ... They only know the truth"' (Sidhwa 1989:192, ellipsis in the original). The employment by both authors of the child character as index to register the palimpsest of impressions of the complex, interplaying influences that affect her or him and that teach both children about the nature of their society and its unfolding processes, allows the reader to learn along with the child, although often understanding more than the child can. These children are not yet actual stakeholders in society and are therefore generally more impartial observers of large events, while intensely concerned with and alert to their immediate (especially familial) circumstances and neighbourhood surroundings.

What Suleiman in Matar's early 1970s Libya sees as one of the most long-term results of the events witnessed by his nine-year-old self, is a lingering dread; a feeling that has "survived well into [his] manhood"; "a kind of quiet panic, as if at any moment the rug could be pulled from beneath my feet". This feeling originated with his watching "the televised execution of Ustath Rashid" (Matar 2006:197), his friend Kareem's father and his own father's friend. Restrained as this statement is, it emphasises a devastating loss; Suleiman knows that anyone may be touched by this terror. For Lenny's part, in Sidhwa's 1947 Pakistan, even though her own circumstances remain and keep her relatively safe, there is one indelible, recurrent image [ascribed to both the naked, speared child used like a crest to proclaim the mob's murderous intentions and Shanta her abducted Ayah's expression] that is both the stuff of nightmares and a sign of children's and women's actual vulnerabilities. When Lenny sees the first outbreak of mob violence, a "crimson fury" absorbs her at the sight of the killed child: "waved like a flag: her screamless mouth agape". When she later watches in helpless agony as her Ayah is taken away by the smaller mob led by Ice-candy-man, Lenny sees that Shanta's "lips are drawn away from her teeth, and the resisting curve of her throat opens her mouth like the dead child's screamless mouth" (Sidhwa 1989:135,183). Matar's and Sidhwa's texts both depict simultaneously the articulate witnessing of children as an index of a society's health or disease, uttering (in Lenny's case) loud or (in Suleiman's case) muted screams on behalf of silenced victims. The disturbance of the ideally sacrosanct space of childhood happiness, sense of safety and innocence signposts how profoundly their societies have gone wrong. 


\section{The child as affective index of the appalling}

These texts function partly as reports on situations and aspects of events that are not widely known in detail in the "outside world" - i.e., the way in which the Ghaddafian dictatorship strengthened its grip on Libyan society and the nature of the resistance to it (also its successful repression of opposition), and the eruption of ethnic violence during the Partition of the Indian subcontinent - more particularly, how this was inflicted on women's bodies and the consequences this had for abducted and violated women. The children who "report" on these processes in the novels do vital witnessing work. Because they are children, the details of the atrocities described by them as if to the reader are in addition conveyed with especial affective intensity. Robert Frost writes of how, to arouse a reader's feeling, a poet needs first to experience and successfully communicate that feeling: "No tears in the writer, no tears in the reader" (1951:18). In a similar process, a child's horror, outrage or fear in witnessing violent and bloody acts, violations of human dignity or outbreaks of hatred and mass rage (in contrast with an adult reporter's) tends to have especially irresistible and undeniable convincing force. The child's sensations and responses have a particular vividness; the child has fewer defences and the ugliness of what (in my title) I term "the politics of cruelty", observed by a child, is described unobscured by ideology, justification, or subterfuge.

In Ice-Candy-Man, the girl Lenny initially responds with a sort of awed excitement (as she is invited to do by the title character) at the sight of a prosperous section of Lahore going up in flames:

I stare [...] mesmerised by the spectacle. It is like a gigantic fire-works display in which stiff figures looking like spread-eagled stick-dolls leap into the air, black against the magenta furnace. Trapped by the spreading flames the panicked Hindus rush in droves from one end of the street to the other. Many disappear down the smoking lanes. Some collapse in the street. Charred limbs and burnt logs are falling from the sky.

(Sidhwa 1989:137)

But then it begins to feel to her as if the "whole world is burning", as if her own "flesh and clothes will catch fire" and she "start[s] screaming: hysterically sobbing" (Sidhwa 1989:137) in shock and horror at the awfulness of the event - its inner meaning rather than its visual details. After Shanta ("Ayah" to Lenny) is later kidnapped by a male mob, the child "throw[s] up. Constantly" (Sidhwa 1989:184). Shanta/Ayah is intensely and tenderly loved by Lenny, and her dilemma is that she was tricked into betraying Ayah's hiding place. Later on, Lenny is present when her influential godmother interrogates Ice-candy-man - who, having led and organised the mob of men who abducted Shanta and gang-raped her, became her pimp and (when Lenny's mother organised for Shanta to return to her Hindu family in Amritsar, India) then married her and exhibited her dancing and singing skills as a performer, renaming her Mumtaz. The now cringing Ice-candy-man, it turns out, is more than ever besotted with the Hindu woman he degraded, then made money from and married (having forced her to convert to Islam). So overwhelmed is Lenny by the terrible, contaminated relationship and the intense, conflicting feelings it arouses in her, that she feels "a suffocating explosion within [her] eyes and head. A blinding blast of pity and disillusion and a savage rage" - her "violently shivering" body perturbs Lenny's godmother, who exclaims in sharp warning: "'Take a deep breath! Come on, inhale!'" (Sidhwa 1989:251). Even after Ice-candy-man has been dismissed, 
Lenny's agony is so intense that she can only express it by biting into her godmother's bodice and chest, drawing blood.

A similar excruciating emotional ambivalence is (depicted as) experienced by the nine-yearold Suleiman in Matar's novel, when the boy's mother, night after drunken night, pathetically appeals to him to understand how her young girl's hopes and dreams were brutally shattered, and to keep the secret of her drinking bouts. At fourteen, her older brother saw her holding hands in a cafè with a boy of the same age. He reported this to her father and other brothers as "spending her days in cafès with strange men" (Matar 2006:147) and she was immediately sequestered in her room while marriage to a 23-year-old stranger was arranged within weeks. She fainted when her husband came to consummate the marriage but, as her mother later informs her, had she not proved to be a virgin, her father would have killed her. Nine months after the marriage, the boy Suleiman was born to the 15-year-old girl - and the especial, unhealthy intensity of her emotional dependence on her young son is the result.

The nine-year-old boy is disturbed by the unsatisfactory quality of his parents' sex life as he obscurely senses it. In addition to this, his insecurities are profoundly intensified by the fact that security policemen follow him and his mother, and by the fact that that his father's friend (their neighbour, whom the boy had idolised as a warm and loving parent, in contrast with his own, more aloof father) is arrested and taken away. The same men soon arrive at their home in search of Suleiman's father, who was away at the time. Their neighbour, under arrest but untraceable by his wife, has already:

"... 'Vanished like a grain of salt in water.' Who have they come to take this time, I wondered: Mama, Moosa [another friend], me? How can any one of us prove that he or she is not, and never was a traitor? [...] I bit on my lip to keep my teeth from chattering. I remembered Baba's words, what he whispered in my ear every time he left us: 'Take care of your mother, you are the man of the house now.' I buried my hands in my armpits, trying to stop trembling."

(Matar 2006:62)

Soon after this, the boy wets himself in terror as the men search their house, which profoundly embarrasses him. Later, when Suleiman's father has gone on the run and his mother and Moosa burn the father's incriminating books (such as one titled Democracy Now, which the boy "rescues"), Suleiman's mother shouts at Moosa, her husband's political acolyte, for how foolish these adult males are to think they can stand up against the might of a military dictatorship. Agonised by fear for his father, Suleiman "[holds his] stomach, double[s] over and beg[ins] rocking"; his "quivering" lips and inadvertent gulps betraying the fact that he is crying to the quarrelling grown-ups (Matar 2006:98,99). He is also horrified that the books his father loves, have been burnt. The boy is by himself, later, when he witnesses the televised interrogation of their neighbour, his father's friend and political ally. Suleiman knows that he has been tortured and that this gentle, civilised person has been horribly degraded - it has happened before. Later on, he watches with his mother and Moosa the televised execution of this friend, detail by excruciating detail: the condemned man weeping, begging for mercy, urinating and vomiting before he dies by hanging (in a baseball stadium) while a huge, ecstatic crowd raucously celebrates this "defeat" of one of the "dangerous" "corrupt elements" (Matar 2006:183) that dared oppose their Leader. The boy decides: "Something was absent in the Stadium, something that could no longer be relied on" (Matar 2006:196-197). When his father is returned to the family after his own incarceration, interrogation and torture, he tries 
to keep the boy from seeing his battered body, but the glimpses Suleiman snatches of his father's horribly swollen and disfigured face merely make the boy believe nightmarishly that a monster has taken up residence in his parents' bedroom.

Probably because she is a child, Lenny is especially aware of the endangerment of children's lives and violations of innocence during the tense Partition period. The day before horrific violence erupts in Lahore, Lenny has a nightmare of "crucified children" (Sidhwa 1989:132), children to whom she ascribes no ethnic identity and with whom she groups herself. Her friend Ranna, their cook's great-grandson who is also eight (the boy having been left for dead in a Sikh attack that lays their Muslim village waste) sees "with a child's boundless acceptance and curiosity" how "men copulated with wailing children" and how "babies" are "smashed against walls" before their "howling mothers" are "brutally raped and killed" (Sidhwa 1988:207).

The reader's awareness that it is a child who witnesses the atrocities evoked here, intensifies the affective dimension of the description. In a world that has grown nearly numb to visual reports of widespread violence and suffering, vividly imagined verbal responses or reported comments by child witnesses still penetrate our hardened hearts with piercing intensity. The observing, horrified or terrified child signals the truly abominable and obscene, indeed the desecrating nature of what happens when ethnic differences are inflamed to validate mass murder and rape, or when tyranny is given hysterical mass support. But children do not know or use the distancing, explanatory terminology of the preceding sentence; they know only that individual human actors commit and make such grotesque deeds possible ${ }^{4}$. The boy Suleiman, poignantly, senses an echo of his own experience in a poem by Salah Abd al-Sabur that is read to him: "Noon, you fill my heart / with fear and dread, showing / me more than I want to see" (Matar 2006:57). Both children are instructed to harden themselves - Suleiman to "firm up" (Matar 2006:100); Lenny (and Ayah) to "make [their] hearts stout" (Sidhwa 1989:137). It is to their profound credit and to the affective instruction of the reader, that Lenny's eyes remain "wide and sombre" (Sidhwa 1989:134) at the awful things she witnesses and that Suleiman contrasts Moosa's "sombre grimace" at the sight of the hangman's loop with the deathlike "blank" look on his mother's face (Matar 2006:183).

\section{Centering the child}

The power of Suleiman's and Lenny's narratives derives to a considerable extent from the fact that, in both novels, not only is the child convincingly imagined, but she or he is unquestionably and throughout (or in at least $90 \%$ of the narrative) at the centre of his or her story. Nor are these novels bildungsromane. We are indeed in Matar's text acquainted with the adult Suleiman, but the narrative is overwhelmingly concentrated in his nine-year old's consciousness, while with Lenny we have only a few scattered sentences referring to her adult self. Even so, it is clear how "the child is [or will be] father of the man" (or woman), to adapt Wordsworth (1888). Both Suleiman and Lenny are indelibly marked by what happens to and around them during the period of the main events of both texts. We learn, along with them, how necessary and impossible it is to "live with" atrocities, and how children experience emotional agony and are confronted with horrors.

The differences between the two child protagonists' personalities are great. In comparing the texts and these children's situations the reader is also taught to what extent parents and surrogate parents exhibit in their children's eyes a blueprint of what life may or may not hold 
for them. Lenny lives a much more sociable life than Suleiman, who is often shut off with only his emotionally demanding mother for company. Although her nightmares alert one to the darker fears Lenny harbours, the little girl is a better sheltered and more cheerfully raised child than Suleiman. She idolises her somewhat remote mother, whose attention to Lenny is intermittent, but she has Shanta/Ayah's gentle, playful daylong companionship and the sheltering and strong love of her beloved Godmother. It is understandable, then, that this eight-year-old girl is much more mature and sure in her judgements than the insecure Suleiman, whose father is so aloof - though also kind and caring - that the boy yearns for a tenderly close filial relationship like his older friend Kareem has with his father, their scholarly neighbour. Moreover, although Suleiman is much more pampered than Lenny, he is treated with less respect, since in their erratic attempts to shelter him from scary realities, the adults around him show too little faith in his judgement and ability to learn, causing the child much emotional confusion. Because of all the terrible, incomprehensible secrets that Suleiman is expected to keep, he is a profoundly repressed boy who becomes a melancholy man; Lenny's more exuberant candour will (as some hints indicate) make her a spirited and outspoken woman. But their devastating losses - by Suleiman, of his parents, friends and country and by Lenny, of her beloved Ayah - will reverberate forever in both children's lives. The uncomprehending, appalled child who witnesses how a virulent "new" nationalism devastates families, friendships and lives gives each narrative its especial resonance.

\section{Corruption of innocence: education in brutality}

In both Matar's and Sidhwa's texts the child protagonists are betrayed into betrayal, subjecting their young personalities to nearly unbearable stresses. Because her mother fails to explain to the child that she and her sister illegally hoard petrol to enable endangered families to escape from Lahore, or to allow raped women to rejoin their people, Lenny imagines that her mother and aunt are "setting fire to Lahore" (Sidhwa 1989:173) and in danger of arrest! The most devastating thing that happens to Lenny, though, occurs when the mob comes to their home intent on "cleansing" it of Hindus, Ice-candy-man kneeling before a trustful Lenny who, believing his reassurance that he will "protect Ayah with [his] life" (Sidhwa 1989:182), is persuaded to give away Shanta's hiding place - thereby making possible the abduction and violent subjection and abjection of the young woman who had long reigned supreme over a varied coterie of male admirers. A week after this, the shamed and devastated child witnesses another awful betrayal: a servant woman's daughter, often severely maltreated by the mother, is drugged to be made the child bride of a much older man in an arranged marriage. And Lenny's own mother, as the little girl learns obscurely, not long after, is violently manhandled by Lenny's father, her husband, apparently for daring to object to his night-time visits to another woman. Lenny's major and most awful learning moment, however, occurs because of Ice-candy-man's conduct and her Godmother's response to it. She states:

The innocence that my parents' vigilance, the servants' care and Godmother's love sheltered in me, that neither Cousin's carnal cravings, nor the stories of the violence of the mobs could quite destroy, was laid waste that evening by the emotional storm that raged round me. The confrontation between Ice-candy-man and Godmother opened my eyes to the wisdom of righteous indignation over compassion. To the demands of gratification - and the unscrupulous nature of desire. To the pitiless face of love.

(Sidhwa 1989:252) 
Lenny's real betrayal of Shanta lies perhaps not in her innocently trustful give-away of Ayah's hiding place, but in her continuing to yield emotionally to Ice-candy-man's "beguiling eyes"

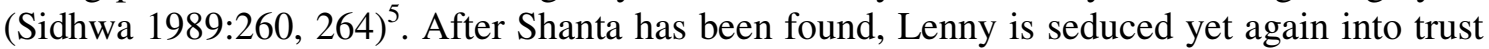
and "compassion" towards Ice-candy-man over "righteous indignation" (Sidhwa 1989:252), despite having seen the formerly glowing-eyed Ayah now transformed into a simulacrum with "vacant eyes", eyes that open "frenziedly, starkly" and that have become "glazed and unfeeling" as well as, simply, "unseeing" (Sidhwa 1989:260, 261, 274, 276).

Suleiman, too, is to an extent manoeuvred into betraying his generous-hearted older friend Kareem, their neighbour's son. His mother is neurotically concerned for the only son whose life has cost her so much, having come about through the destruction of her own youth and prospects by a forced childhood marriage. So fanatically protective is she towards Suleiman that she warns the boy to break off or at least cool down his friendship with Kareem - afraid of guilt by association after Kareem's father was taken by the secret police. She disguises the political reason for her warning by telling Suleiman not that he should convey compassion to Kareem for the danger this boy's arrested father is in, but that he should avoid contamination by Kareem's "sadness". Yet Suleiman knows that the expression in Kareem's eyes is "the sadness of betrayal" (Matar 2006:40) by himself. Later on, Suleiman more publicly betrays and humiliates Kareem, even though he is privately ashamed and remorseful afterwards. It is thus as if, once wrongly steered into betrayal, he cannot stop. Later, in a grotesque parody of paedophiliac seduction, Suleiman is invited to "touch" and handle the "black and fat" gun of the awful state spy who is lying in wait for Suleiman's father in a car that is parked daily in front of their house (Matar 2006:131). He also yields to the flattery of the spy who has tapped their phone, providing the information of his father's group's hideaway location, leading to the arrest of his father's assistant and, possibly, also his father's capture.

From having wanted to become the kind of man who would have rescued a girl like his mother from her fate, Suleiman starts aspiring to masculinity as a power role. He has no understanding of the way the security policeman is "pulling" (Matar 2006:130) him in with platitudes and false, challenging flatteries like "'Men are never afraid. And you are a man, aren't you?'" (Matar 2006:131-132). The boy becomes eager to serve this man and provide him with information - supposedly, knowledge that would help his father. In an obscure way, Suleiman's early spotting of his father in the city when the latter was supposedly abroad on business - the father close enough to touch but the boy remaining unnoticed and unrecognised and never made privy to any reason for the masquerade and deception - prefigured the later, irresistible blurting out of information to an appreciative adult male ear (Matar 2006:140141).

Both novelists disquietingly indicate the vulnerability of "innocent" children to cruelty, not only as its victims, but by showing how children in disturbed environments may themselves become perpetrators, contaminated by or mimicking its violence. Lenny does so mainly symbolically when, having seen a mob tie the legs of a man to two vehicles parked back-toback, ripping his body apart, she returns home and in an hysterical frenzy does the same with a doll. In Suleiman's case he first stones and later almost drowns an elderly, mad beggar. Lenny's strange and "cruel" act of seemingly "pointless brutality", after which she "collapse[s]", "sobbing" (Sidhwa 1989:139), is probably an acting out of the little girl's shock, horror and fear at what she witnessed, and her subsequent tears contrast with and show up the mob's insane remorselessness. Suleiman stones the old beggar man half in fear because he had seemed to detect his mother's secret drinking, and the boy is terrified that this will be revealed 
(Matar 2006:119). His next and worse act of cruelty, however, obscurely echoes the relationship between the baying Stadium crowd and the abject man (Kareem's father) who is hanged - the boy feels an ugly, "secret rush of power" when he terrorises the old man (who cannot swim) into jumping into the sea and then, like any dictator, justifies not only not rescuing him, but preventing him from emerging from the water. Having kicked the old man in the face, Suleiman tells himself at the sight of the old man's bleeding face that "[s]alty sea water is good for a wound" (Matar 2006:217, 218). Yet his "heart" does [ache] afterwards, and a convoluted blending of shame and regret finds expression in Suleiman's sad longing for Kareem, the friend he has betrayed and lost (Matar 2006:219).

Like Lenny, Suleiman learns about pitiless power realities and the imbrication of gender roles in the political patterns of a society. In order to persuade a powerful security police officer (another of their neighbours) to get her husband freed, Suleiman's mother bakes a cake for this terrifying man and his awful wife, whom she and her husband had always despised and detested, and pays them a placatory visit. "[T]hat day", Suleiman informs us, was his "inauguration into the dark art of submission" (Matar 2006:157). The boy observes coolly, concerning the neighbouring official: "[m]ost of us secretly admired his power in comparison with our parents" (Matar 2006:160). Suleiman understands obscurely that, "[i]n a time of blood and tears", he "was the ridiculous child craving concern" (Matar 2006:166) - and that his selfish but natural craving for "concern" is darkly connected to behaviour like the mob's in the Stadium at the hanging; hysterically celebrating the beloved Leader's victory over "[t]raitors who despise and envy ['their'] revolution" (Matar 2006:179). To save him from military conscription at fourteen, at the age of nine Suleiman is sent away to Egypt, never to see his father or his fatherland again. His own final, vengeful betrayal of his mother had been to sever communication with her, embittered by his losses; but in the end, he allows her to rejoin him.

\section{Conclusion}

Both books discussed in this paper depict tender and loving men, while also highlighting the extent to which pitiless power has been given a masculinist aspect, and yet also shows how weak men can be. The texts depict the two children learning about both female strength and vulnerability; about some of the intricacies of adult sexual relationships and about the ways in which even brave women like their respective mothers are sometimes forced to resort to undignified willingness in negotiations with more powerful men. Both texts show children glimpsing the awful complications of love and longing. Their arresting and deeply moving witnessing to their societies, allowing us to perceive along with them, is unforgettable. These child voices function in their humaneness, as in their lapses (when they parrot adult perspectives), as countervailing representations of societies caught (at the time represented) in terrible downward spirals of violence and repression. The novels can be taken as reminders of Shakespeare's resonant image, describing a situation anticipated by the warlord and impending murderer Macbeth, of "Pity like a naked newborn babe, / Striding the blast, or heaven's cherubin, horsed / Upon the sightless couriers of the air," which (as he fears) "Shall blow the horrid deed in every eye / That tears shall drown the wind" (1.7.21-25). This complex metaphor suggests that there may be something stronger in compassion than in pitiless power and that the arousal of compassionate horror and wrath at evil and violence committed against vulnerable victims can compel some human beings to act against those who lay waste to our world by their ruthlessness. In the poignancy with which Matar and Sidhwa depict their child narrators' observations, they arouse this kind of powerful pity. 


\section{Notes}

1. The novel was retitled Cracking India in the later, American edition (2006 [1991]).

2. Compare Dennis Walder (2007:194-195): "The value of postcolonial theory and criticism lies in its attention to forms of cultural representation, especially literary representation, in a way that is alive to the claims of contemporary history and politics...".

3. Matar's family had to go into exile from Libya to Egypt when he was a boy of nine. When Matar was a student in the UK, his father (a Libyan pro-democracy activist) was abducted from Egypt to a Libyan jail. Matar's father was believed to have been killed in a jail massacre in the late nineties, although quite recently there were signs that he might still be alive (Matar 2010). Sidhwa was a girl in her Parsee family home in Lahore when the Partition violence broke out. When she as an adult divorced, she was not allowed to take her son from India with her back to Pakistan (where she lives, although she also lectures in the USA) (Sidhwa 2008).

4. See the passage in Sidhwa (1988:214) where Lenny rejects Hamila's ascription of her dreadful experiences (abduction, rape and the impossibility of returning to her husband and children - since in the former's eyes she is now a "fallen woman") to "fate"; Lenny insists that such things as Ayah's abduction happen because of "the will of men".

5. Compare Lenny's perception (just before she gives him the information about Ayah's hiding place) of Ice-candy-man's "amber-eyed, [...] hypnotic, reassuring" face (Sidhwa 1989:182).

\section{References}

Achebe, Chinua. 1975. Morning Yet On Creation Day: Essays. London: Heinemann.

Bakhtin, Mikhail M. 1990 [1975]. The Dialogic Imagination: Four Essays. In M. Holquist (ed.). translated by C. Emerson and M. Holquist. Austin: University of Texas Press.

Bruschi, I. 2008. Making up with Painful History: the Partition of India in Bapsi Sidhwa's Work. Journal of Commonwealth Literature 43 (3): 141-149.

Dickens, Charles. 1974 [1860]. Great Expectations. Harmondsworth: Penguin.

Didur, J. 1998. Cracking the Nation: Gender, Minorities, and Agency in Bapsi Sidhwa's Cracking India. ARIEL: A Review of International English Literature 29 (3): 43-64.

Frost, Robert. 1951. Complete Poems of Robert Frost. London: Jonathan Cape. pp.17-20.

Gagiano, A. 2007. The African Library - Rubrieke/Columns, LitNet. Entry on In the Country of Men. Available online at http://www.litnet.co.za/cgibin/giga.cgi?cmd=cause_dir_ news\&cat=211\&cause_id=1270. Accessed 8 April 2010.

Hai, A. 2000. Border work, border trouble: Postcolonial feminism and the Ayah in Bapsi Sidhwa's Cracking India. Modern Fiction Studies 46(2): 379-426.

James, Henry. 1998[1897]. What Maisie Knew. Oxford: Oxford University Press.

Jumbam, Kenjo. 1980. The White Man of God. Oxford: Heinemann.

Lara, M.P. 1998. Moral Textures: Feminist Narratives in the Public Sphere. Berkeley: University of California Press.

Laye, Camara. 1955 [1953]. The African Child. Trans. J. Kirkup. London: Collins.

Lee, Harper. 1966 [1960]. To Kill a Mockingbird. Harmondsworth: Penguin.

Mann, H.S. 1994. Cracking India: Minority women writers and the contentious margins of Indian nationalist discourse. Journal of Commonwealth Literature 29 (2): 71-94.

Matar, Hisham. 2006. In the Country of Men. London: Viking [Penguin]. 
Matar, H. 2010. The books interview: Hisham Matar. Available online at http://www.newstatesman.com/books/2010/01/interview-father-prison. Accessed 14 July 2010.

McEwan, Ian. 2001. Atonement. London: Jonathan Cape.

Mitra, M. 2008. Contextualizing Ayah's abduction: Patterns of violence against women in Sidhwa's Cracking India. ARIEL: A Review of International English Literature 39 (3): 23-44.

Moore-Gilbert, B. 1997. Postcolonial theory: Contexts, practices, politics. London:Verso.

Narayan, R.K. 1980 [1935]. Swami and friends. Chicago: University of Chicago Press.

Okri, Ben. 1991. The famished road. London: Jonathan Cape.

Priebe, R. 2006. Transcultural identity in African narratives of childhood. African Literature Today 25: 41-52.

Roy, Arundhati. 1997. The God of small things. New York: Random House.

Rushdie, Salman. 1980. Midnight's children. New York: Knopf.

Scanlan, M. 2010. Migrating from terror: The postcolonial novel after September 11. Journal of Postcolonial Writing 46 (3-4): 266-278.

Shakespeare, William. 1988. Macbeth. In The complete works of William Shakespeare. Oxford: The Clarendon Press.

Sidhwa, Bapsi. 1989 [1988]. Ice-Candy-Man. New Delhi: Penguin Books India.

Sidhwa, Bapsi. 2006 [1991]. Cracking India. Minneapolis: Milkweed Editions.

Singh, S. 2004. Postcolonial Children: Representing the Nation in Arundhati Roy, Bapsi Sidhwa and Shyam Selvadurai. Wasafiri 41: 13-18.

Spivak, G.C. 2003. Death of a Discipline. New York: Columbia University Press.

Stevens, Wallace. 1990 [1954]. The collected poems. New York: Vintage.

Twain, Mark. 1966 [1884]. The adventures of Huckleberry Finn. Harmondsworth: Penguin.

Walder, D. 2007. Decolonising the (distance) curriculum. Arts and Humanities in Higher Education: An International Journal of Theory, Research and Practice 6(2): 187-196.

Wordsworth, William. 1888. My heart leaps up when I behold. In The Complete Poetical Works. London: Macmillan and Co. 